American Journal of Agricultural and Biological Sciences 3 (4): 661-665, 2008

ISSN 1557-4989

(C) 2008 Science Publications

\title{
Taxonomic Significance of ISTR to Discriminate Species in Agavaceae
}

\author{
${ }^{1}$ Martha Isabel Torres-Morán, ${ }^{2}$ Norma Almaraz-Abarca, ${ }^{1}$ Ana Paulina Velasco-Ramírez, \\ ${ }^{2}$ Vicente Hernández-Vargas, ${ }^{2}$ Gildardo Orea-Lara, \\ ${ }^{2}$ Armando Cifuentes-Díaz de León and ${ }^{3}$ Carmen Oliver-Salvador \\ ${ }^{1}$ Centro Universitario de Ciencias Biológicas y Agropecuarias, \\ Universidad de Guadalajara, Km 15.5 Carretera a Nogales. Zapopan, Jalisco, México. \\ ${ }^{2}$ Centro Interdisciplinario de Investigación Para el Desarrollo Integral Regional, \\ Unidad Durango, Instituto Politécnico Nacional, Becarios (COFAA) \\ ${ }^{3}$ UPIBI-Instituto Politécnico Nacional
}

\begin{abstract}
Family Agavaceae is endemic of American Continent. From the around 300 species recognized in this family, 217 occur in Mexico. Relevant ethnobotanic relationships among Agavaceae and the several native human cultures of the American Continent have been established since prehispanic times. Agave is one of the most important genus in that family due to its great diversity and abundance, mainly in arid and semiarid regions of Mexico. In this country, near to 15 species of Agave are used to elaborate alcoholic beverages. Agave tequilana weber var. azul is indubitable the most important of them because is the raw material to elaborate a particular worldly famous class of mescal, named tequila. Agave salmiana, A. maximiliana and A. durangensis are species less famous than A. tequilana, but they also have a high quality and level of carbohydrates and in fact, support local mescal industries. In these last species several taxonomic controversies exist concerning their specific delimitation. In this study the molecular characterization of eight species of Agavaceae using ISTR was performed in order to determine the significance of these markers for discriminating among specific taxa. The results suggest that these molecular markers are worthy to typify species of Agavaceae and detect intrapopulation variability.
\end{abstract}

Key words: Agavaceae, retrotansposons, DNA markers, ISTR

\section{INTRODUCTION}

Agavaceae is an endemic family of the American Continent, found from southern Canada to Northern Sudamerica ${ }^{[1]}$. This family reaches its highest levels of richness and diversity in Mexico, which is considered center of origin of Agavaceae ${ }^{[2]}$.

Citological, morphological, chemical, biogeographical $^{[3]}$ and molecular ${ }^{[4,5]}$, evidences, may recognize Agaveaceae as a taxonomic family divided in two subfamilies: Yuccoideae and Agavoideae. Subfamily Yuccoideae including two upper-ovary genera: Yисса y Hesperaloë and subfamily Agavoideae including, according to García-Mendoza and Galván ${ }^{[1]}$, eight lower-ovary genera: Agave, Beschorneria, Furcraea, Manfreda, Polianthes and Prochnyanthes, but according to Rocha et al. ${ }^{[6]}$, besides the former ones, the genus Hesperoyucca is also included.

Among the $293^{[7]}$ or 300 species $^{[6]}$ recognized in the family Agavaceae, 217 occurre in Mexico ${ }^{[1]}$. One hundred and fifty five species are recognized as endemic. The most rich States in Agavaceae are, in decrease order, Oaxaca with 52 taxa, Durango and Puebla with 43 and Sonora and Jalisco with $40^{[1]}$.

Agave is the biggest genus in Agavaceae, with around 166 species, from which 125 grow in Mexico $^{[1,6]}$. The relevant ethnobotanic relationships between the elements of this genus and the ancient and present cultures of Mexico have been well documented ${ }^{[8,9]}$. Several authors have described the use of Agave as source of fibers, food and beverages ${ }^{[10]}$. The jesuita José de Acosta describes Agave as "El árbol de las maravillas, del que los nuevos o chapetones (como en Indias los llaman), suelen escribir milagros, de que da agua y vino, y aceite y vinagre, y miel, y arrope e hilo, y aguja y otras cien cosas" (Historia Natural y Moral de las Indias, 1590) ${ }^{[11]}$. In addition, Agave is used as natural fences to avoid the soil erosion and as cattle food ${ }^{[12]}$. However, only few reported uses yet prevail and have been transformed throughout the time.

Corresponding Autor: Martha Isabel Torres-Morán, Centro Universitario de Ciencias Biológicas y Agropecuarias, Universidad de Guadalajara, Km 15.5 Carretera a Nogales, Zapopan, Jalisco 
At the present, the relevance of Agave has increased meanly because of the increased demand of alcoholic beverages like tequila ${ }^{[13]}$ and mescal ${ }^{[14]}$ but also due to the research on potential sources of prebiotics ${ }^{[15]}$. In all the cases, the authentification of the species of Agave to be used is an important requirement in the quality control of the manufacturing processes. In Mexico, with exception of Agave tequilana Weber var. azul, species like Agave durangensis, which support local industries of alcoholic beverages and which with just begin an industrialization process, techniques are needed to guarantee the botanical origin of plants, according to the respective origin denomination statement. Molecular characterization is an important technique, which with plant typification and identification can be made in a relative easy and fast manner ${ }^{[16]}$.

Several marker systems are based on retrotransposons ${ }^{[17,18]}$, these markers are a ubiquitous and ancient particular class of transposable elements of plant genome ${ }^{[19]}$, replicating through a cycle of successive transcription, reverse transcription and integration into genome ${ }^{[20]}$. Inverse Sequence Tagged Repeats (ISTR) is a molecular marker based on retrotransposons, using encoded reverse transcriptase sequences bounded by copia-like elements. ISTR has showed to be a worthy molecular tool to detect intrapopulation variability in economically important cultivars of coffee, soya, Agave tequilana, Agave fourcroydes and Agave cocui ${ }^{[21-26]}$. In this study the molecular characterization of eight species of Agavaceae (Furcraea sp. (L.) Haw, Agave americana L., Agave guadalajarana Trelease, Agave maximiliana (Berger) Gentry, Agave salmiana Otto, Agave desmettiana Jacobi, Agave angustifolia Haw, Agave tequilana Weber and Agave durangensis) was performed, using ISTR, in order to determine the significance of these markers to typify and discriminate among these species of Agavaceae and detect intrapopulation variability.

\section{MATERIALS AND METHODS}

Plant material: Leaves of Furcraea sp., A. americana, A. desmettiana, A. maximiliana, A. salmiana, A. tequilana and $A$. angustifolia were obtained from four different individuals of each species, growing in the Agavetum of Centro Universitario de Ciencias Biológicas y Agropecuarias, Universidad de Guadalajara (UdG), México. These seven all taxa were identified by Ana Lilia Vigueras, botanist of UdG. Leaves of Agave durangensis were also collected from four plants growing in a natural population in Sierra de Registro, Durango, México (2359.4' 38' N, 104²2.5' 13 ' W, $1928 \mathrm{~m}$ ), reference samples were deposited in Herbarium CIIDIR.

DNA extraction: Total DNA of each sample was prepared from leaves using the CTAB procedure of Keb-Llanes et al. ${ }^{[27]}$.

ISTR analysis: Retrotransposon fragments were amplified using the following primer pairs F9/B6 (d5' [TTA CCT CCT CCA TCT CGT AG]3'/d3' [GGT TTC ACT TTG TCC TTA G]5'), and FI/B6 (d5' [GCA CTC CAC CAA GAA TAC C] 3'/d3' [GGT TTC ACT TTG TCC TTA G]5'). PCR amplifications were performed according to Osorio et al. ${ }^{[23]}$, on $2.5 \mathrm{ng}$ of DNA in $20 \mu \mathrm{L}$ reaction volumes containing 0.25 units of Taq DNA polimerase (Promega $\left.{ }^{\circledR}\right), 3 \mathrm{mM} \mathrm{MgCl}$, $0.3 \mu \mathrm{M}$ each primer, $0.25 \mathrm{mM}$ each dNTP and the buffer supplied with the enzyme. Cycling conditions were $3 \mathrm{~min}$ at $95^{\circ} \mathrm{C}$ followed by 40 cycles of $30 \mathrm{sec}$ at $95^{\circ} \mathrm{C}$ and annealing at $45^{\circ} \mathrm{C} 1 \mathrm{~min}$ and extension at $72^{\circ} \mathrm{C} 2 \mathrm{~min}$.

Amplification fragments were analyzed by denaturing polyacrilamide gels $6 \%$. Samples were electrophoresed at $200 \mathrm{~W}$ constant power and stained with silver salts, according to Sanguinetti et al.$^{[28]}$.

Data analysis: The amplification profile of each sample was made up of all fragments resolved in their respective electropherogram. Each fragment was treated as a single molecular character. A binary (presenceabsence) matrix formed by all individual samples ( 32 fragments vs. 32 individuals) was analyzed using the unweighted paired group of arithmetic averages method (UPGMA). Similarity coefficients were estimated using the program NTSYS 2.11 .

\section{RESULTS AND DISCUSSION}

In order to demonstrate the reproducibility and consistency of ISTR results in the eight species of Agavaceae analyzed, DNA of the same leaves was extracted and amplified with the same primer combination by duplicate in different days. The ISTR profiles were reproducible (Fig. 1).

Thirty two fragments (or loci) of the reverse transcriptase domain were amplified from the eight taxa of Agavaceae analyzed (Fig. 1). These results represent a strong contrast with most of the reports on ISTR markers indicating that a large number of loci are detected in a single ISTR analysis ${ }^{[24,29,30]}$, particularly with those of reported for Agave fourcroydes, in which 
from 94-111 loci were detected ${ }^{[29]}$. Our results also represent a contrast with the 43-135 loci detected with AFLPs for eight species of Agave ${ }^{[31]}$ and with the 93262 loci founded also with AFLPs for several varieties of Agave tequilana Weber ${ }^{[16]}$, but are according to the results of Torres-Morán et al. ${ }^{[26]}$ on different plantations of Agave tequilana Weber var. azul, who reported profiles composed by 35 amplification fragments, using the same ISTR pairs of primers, and with the 24-48 loci detected for eight species of Agave by Infante et al. ${ }^{[31]}$.

Only one amplified fragment was common to the eight taxa of Agavaceae analyzed. This could represent a family marker, as long as it would be found in more species of Agavacea treated with the same pair of primers.

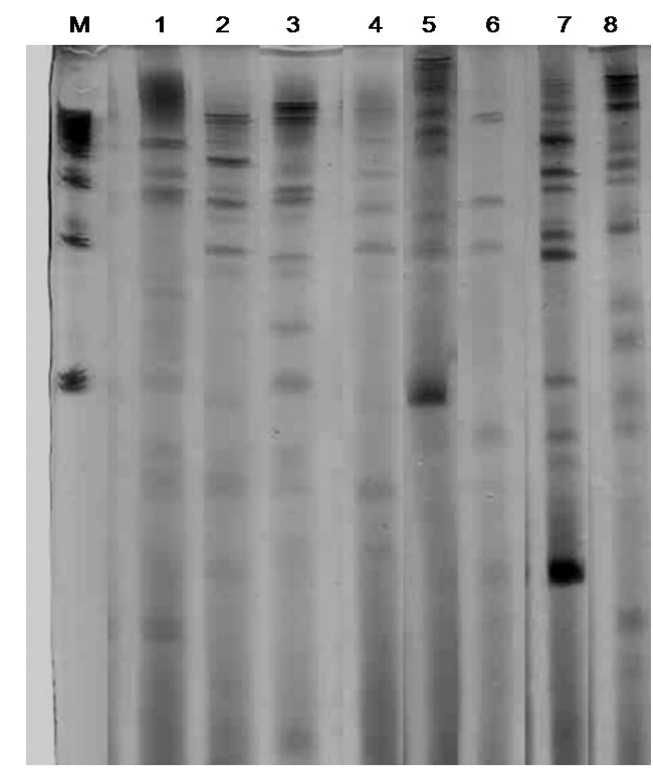

Fig. 1: Typical banding pattern founded using ISTR for eight species of Agave. $\mathrm{M}=200 \mathrm{pb}$ leader, $1=A$. angustifolia, $2=A$. maximiliana, $3=A$. americana, $\quad 4=A$. desmettiana, $5=A . \quad$ salmiana,$\quad 6=$ Furcraea sp., $7=$ A. tequilana and $8=A$. durangensis

According to Fig. 1, the number of amplified fragments per species was variable, six fragments were found in every individual of Furcraea sp., 16 were found in A. salmiana, 14-17 in A. tequilana, seven in $A$. desmetiana, 6-12 in $A$. americana, 7-10 in $A$. maximiliana, 8-9 in A. angustifolia and 13-14 in $A$. durangensis. Despite the observed variability in $A$. tequilana, A. amaricana, $A$. maximiliana and $A$. durangensis, each analyzed taxon displays a unique ISTR amplification profile.
The UPGMA analysis clearly distinguishes two groups (Fig. 2). One group was formed by A. angustifolia, A. maximiliana, A. desmetiana and A. americana (group I) and other group formed by A. salmiana, A. durangensis, A. tequilana and Furcraea sp. (group II).

ISTR markers display a close relationship between Furcraea sp. and the group II of Agave, although clearly separated (Fig. 2). Contrary to that stated on morphological basis by Gentry ${ }^{[8]}$, A. angustifolia and A. tequilana, two species belonging to the same group Rigidae, are grouped separately in this analysis.

The UPGMA analysis indicates that each of these eight species of Agavaeae can be distinguished from the others by a unique ISTR amplification profile. Although it was affirmed that markers revealing a great number of loci are more efficient in revealing polymorphisms $^{[16]}$ the number of fragments obtained from ISTR analysis is enough to revel intrapopulation variability. Our results suggest that ISTR markers could be used in taxonomic analysis to delimitate and discriminate among species of Agavaceae.

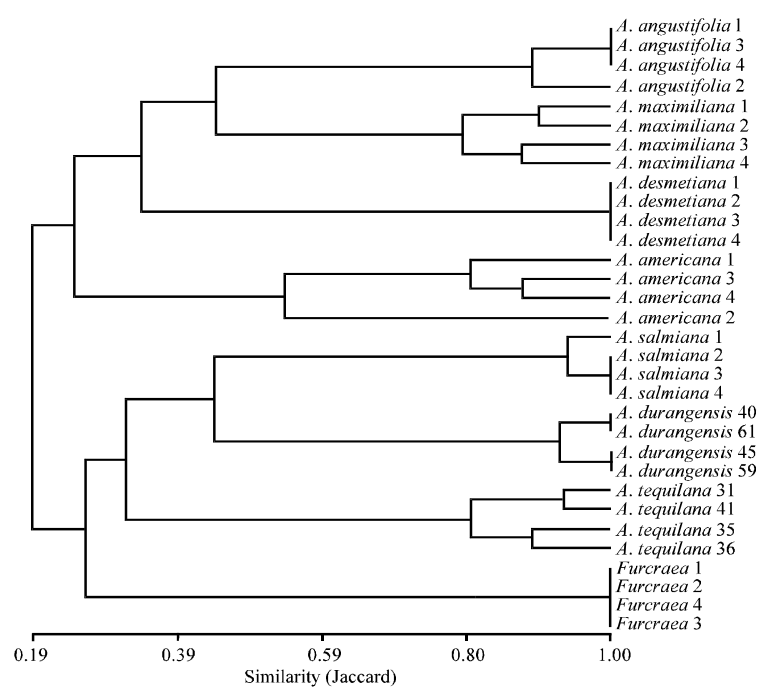

Fig. 2: Results of clustering depicting similarity among four individuals for eight Agavaceae species

ISTR amplification profiles confirm specific taxonomic separation made on a morphological basis. The eight species of Agavaceae are clearly distinguished from each other (Fig. 2).

ISTR profiles displayed variability in A. angustifolia, A. maximiliana, A. americana, A. salmiana, A. durangensis and A. tequilana (Fig. 2). This suggests that these markers could be worthy to detect intrapopulation variability in those species. 
Previously, it has been reported genetic variability detected by ISTR among asexually propagated plants of A. fourcroydes ${ }^{[32]}$ and in micropropagated plants of A. tequilana ${ }^{[25]}$ despite the expecting fact that those plants should be genetically identical.

\section{CONCLUSION}

ISTR markers are well distributed in the eight taxa of Agavaceae analyzed in this study, in a such a way that it is possible distinguish species-specific profiles. The complex pattern of retrotransposon polymorphism enables the discrimination among these species from the patterns of shared and unique bands. These profiles can be considered a valuable molecular marker at specific level in Agavaceae. Although more population studies on the distribution of ISTR markers among more species of this family are needed, these results suggest that ISTR profiles could be specific taxonomic markers in Agavaceae.

\section{ACKNOWLEDGMENT}

The authors wish to thank CONACyT for the support (60664-CB-2006-1) provided to this research.

\section{REFERENCES}

1. García-Mendoza, A. and R. Galván, 1995. Riqueza de las familias Agavaceae y nolinaceae en México. Bol. Soc. Bot. México, 56: 7-24. ISSN 0366-2128.

2. García-Mendoza, A., 1995. Richness of family Agavaceae in México. In: Conservation of Plants under threat. Linares, E., P. Dávila, F. Chiang, R. Bye and T. Elias (Eds.). UNAM, México, pp: 59-83. ISBN 968-36-4540.

3. Dalhgren, R.M.T., H.T. Clifford and P.F. Yeo, 1985. The Families of the Monocotyledons. Structure, Evolution and Taxonomy. SpringerVerlag, Berlin, pp: 520. ISBN: 3-540-13655-X.

4. Bogler, J.D. and B.B. Simpson, 1995. A chloroplast DNA study of the Agavaceae. Syst. Bot., 20 (2): 191-205. ISSN 0363-6445

5. Eguiarte, L.E., M.R. Duvall, G.H. Learn and M.T. Clegg. 1994. The systematic status of the Agavaceae and Nolinaceae and related Asparagales in the monocotyledons: An analysis based on the $r b c \mathrm{~L}$ gene sequence. Bol. Soc. Bot. México, 54: 35-56. ISSN 0366-2128.
6. Rocha, M., S.V. Good-Ávila, F. Molina-Freaner, H.T. Arita, A. Castillo, A. García-Mendoza, A. Silva-Montellano, B.S. Gaut, V. Souza and L.E. Eguiarte, 2006. Pollination biology and adaptative radiation of Agavaceae, with special emphasis on the genus Agave. Aliso, 22 (1): 327-342. ISSN 006-6275

7. Good-Ávila, S.V., V. Souza, B.S. Gaut and L.E. Eguiarte, 2006. Timing and rate of speciation in Agave (Agavaceae). Proc. Natl. Acad. Sci., 103: 9124-9129. Doi: 10.1073/pnas.0603312103.

8. Gentry, H.S., 1982. Agaves of Continental North America. The University of Arizona Press,. Tucson. $1^{\text {st }}$ Edn. ISBN 0-8165-0775-9.

9. Arizaga, S. and E. Ezcurra. 2002. Propagation mechanisms in Agave macroacantha (Agavaceae), a tropical arid-land succulent rosette. Am. J. Botany, 89 (4): 632-641. URL: http://intl.amjbot.org.

10. Colunga-GarcíaMarín, P., A. Larqué, L.E. Eguiarte and D. Zizumbo-Villarreal, 2007. Introduction. In: In The Ancestral There Is Future. Centro de Investigación Científica de Yucatán, México, pp: 5-12. ISBN: 978-968-6532-18-0.

11. Ramírez, J., 1995. The magueyes, plants with thousand of uses. Biodiversitas 1 (1): 1-7. ISSN 1870-1760.

12. Colunga-GarcíaMarín, P. and D. ZizumboVillarreal, 2007. The Tequila and other Mescales from Central and Western Region of México: Domestication, Diversity and Germoplasm Conservation. In: In The Ancenstral There Is Future. Centro de Investigación Científica de Yucatán, México, pp: 113-131. ISBN: 978-9686532-18-0.

13. Bowen, S. and P. R. W. Gerritsen, 2007. Socioeconomic and Ecological forces driving the expansion of Agave cultivation in southern Jalisco, Mexico. In: Agaves from the Western Mexico. Vázquez-García, J. A., M. J. Cházaro, G. Hernández, E. Flores and Y. L. Vargas-Rodríguez, (Eds.) U. de G., CUCBA-CUCSH, Lousiana State University, CONAFOR, Mexico, pp: 182-198. ISBN 978-970-27-1293-0

14. Valenzuela-Ruíz, J.F., O.H. Velasco-González and M.A. Márquez-Linares, 2003. Sustanaible development of Agave Mezcalero in Durango, México. $\quad 1^{\text {st }} \quad$ Edn., SEP, CIIDIR-IPN-Dgo., SAGAR. México. ISBN P70-93232-2-9.

15. López, M.G., N.A. Mancilla-Margalli and G. Mendoza-Díaz, 2003. Molecular structure of fructans from Agave tequilana Weber var. azul. J. Agric. Food Chem., 51: 7830-7840. Doi: 10.1021/jf030383v. 
16. Gil-Vega, K., C. Díaz, A. Nava-Cedillo and J. Simpson. 2006. AFLP analysis of Agave tequilana varieties. Plant Sci., 170 (4): 904-909. Doi: 10.1016/j.plantsci.2005.12.014.

17. Flavell, A.J., M.R. Knox, S.R. Pearce and T.H.N. Ellis, 1998. Retrotransposon-Based Insertion Polymorphisms (RBIP) for high throughput marker analysis. Plant J., 16: 643-650. Doi: 10.1046/j.1365-313x.1998.00334.x.

18. Pearce, S.R., C. Stuart-Royers, M.R. Knox, A. Kumar, T.H.N. Ellis and A.J. Flavell, 1999. Rapid isolation of plant Ty1-copia group retrotransposons LTR sequences for molecular marker studies. Plant J., 19 (6): 711-717. Doi: 10.1046/j.1365313x.1999.00556.x.

19. Wessler, S.R., T.E. Bureau and S.E. White, 1995. LTR-retrotransposons and MITES-important players in the evolution of plant genomes. Curr. Opinion Genetics Dev., 5 (6): 814-821. Doi: 10.1016/0959-437X(95)80016-X

20. Vicient, C.M., R. Kalendar and A.H. Schulman, 2001. Envelope-Class retrovirus-like elements are widespread, transcribed and spliced and insertion ally polymorphic in plants. Genome Res., 11 (12): 2041-2049. Doi: 10.1101/gr.193301.

21. Esayas, A., 2005. Molecular genetic diversity study of forest coffee tree (Coffea arabica L.) populations in Ethiopia: Implications for conservation and breeding. Acta Univ. Agric. Sueciae, 79: 1-10. URL: http://dissepsilon.slu.se/archive/00000918/

22. Infante, D., G. González, L. Peraza-Echeverría and M. Kb-Llanes, 2003. Asexual genetic variability in Agave fourcroydes. Plant Science, 164 (2): 223230. Doi: 10.1016/S0168-9452(02)00404-1.

23. Osorio, Z., M.A., D. Infante and S. Molina, 2006. Asexual genetic variability in Agave cocui Trelease. Bol. Nakari, 17: 1-7. ISSN 1405-1613.

24. Rohde, W., 1996. Inverse Sequence Tagged Repeat (ISTR) analysis, a novel and universal PCR based technique for genome analysis in plant and animal kingdom. J. Genet. \& Breed., 50 (3): 249-261. URL: http://www.cerealicoltura.it/.

25. Torres-Morán, M.I., M.M. Morales-Rivera, L. De La Cruz and A. Villalobos, 2006. Identification of polymorphisms among offshoots and micropropagated plants of Agave tequilana and Agave cocui using ISTRs. Scientia CUCBA, 8: 203-206. ISSN 1665- 8493. URL: http://www.cucba.udg.mx/new_publicaciones/page _scientia_cucba/scientia-cucba.htm
26. Torres-Morán, M.I., M. Morales.Rivera, R. NuñoRomero, F. Santacruz-Ruvalcaba and A. Rodríguez. 2007. Variability in Agave tequilana Weber var. azul detected in micropropagation at a molecular level. Bol. Nakari, 18: 3-5. ISSN 1405. URL: http://www.nakari.go.to.

27. Keb-Llanes, M., G. González, B. Chi-Manzanero and D. Infante, 2002. A rapid and simple method for small scale DNA extraction in Agavaceae and other tropical plants. Plant Mol. Biol. Report., 20 (3): 299. Doi: 10.1007/BF02782465.

28. Sanguinetti, C.J., E. Días Neto and A.J. Simpson, 1994. Rapid silver staining and recovery of PCR products separated on polyacrilamide gels. Biotechniques, 17 (5): 914-921. URL: www.biotechniques.com

29. Demey, J.R., E. Gamez, S. Molina and D. Infante, 2004. Comparative study of the discriminating capacity of AFLP and ISTR markers for genetic analysis of Agave fourcroydes. Plant Molecular Biol. Reporter, 22(1): 29-35. Doi: 10.1007/BF02773346.

30. Sensi, E., R. Vignani, W. Rohde and S. Biricolti, 1996. Characterization of genetic biodiversity with Vitis vinifera Sangiovese and Colorino genotypes by AFLP and ISTR DNA marker technology. Vitis, 35 (4): 183-188. ISSN 0042-7500.

31. Infante, D., S. Molina, J.R. Demey and E. Gámez, 2006. Asexual genetic variability in Agavaceae determined with inverse-sequence-tagged repeats and amplification fragment length polymorphism analysis. Plant Mol. Biol. Report., 24( 2): 205-221. ISSN 0735-9640.1613.

32. Infante, D., M. Osorio, S. Molina and G. González, 2007. Genetic improvement of asexually propagated plants. Acta Hort., 738: 721-728. URL: www.actahort.org. 